International Journal of Social Science And Human Research

ISSN(print): 2644-0679, ISSN(online): 2644-0695

Volume 04 Issue 12 December 2021

DOI: $10.47191 / \mathrm{ijsshr} / \mathrm{v} 4-\mathrm{i} 12-75$, Impact factor-5.586

Page No: 3986-3990

\title{
Evaluating Learning Media on Mathematical Literacy Through Student's Logical Thinking Skill: Mobile Learning Integrated Ethnomathematics as Strategy to Improve Student's Logical Thinking Skill
}

\author{
Nur Julianto $^{1}$, Triana Rejekiningsih ${ }^{2}$, Muhammad Akhyar ${ }^{3}$ \\ ${ }^{1,2,3}$ Postgraduate Program, Sebelas Maret University, Surakarta 57126, Indonesia
}

\begin{abstract}
This study aims to evaluate learning media on mathematical literacy towards the achievement of logical thinking skills and determine strategies to build students' logical thinking skills. The subject in this study were 79 fifth-grade primary school students in Surakarta and Boyolali. The data in this study is quantitative data and qualitative data. The instrument used to collect quantitative data was a mathematical literacy test consisting of five aspects of logical thinking skills that are understanding, planning, determining, solving, and conclusion. The instrument used to collect qualitative data was the scientific journal. The results showed that percentage achievement of students' logical thinking skills in solving mathematical literacy is understanding $(55,82 \%)$, planning $(51,08 \%)$, determining $(47,85 \%)$, solving $(41,52 \%)$, and conclusion $(31,14 \%)$. The data shows that learning media in elementary school could not be building students' logical thinking skills. One strategy which can be used to build students' logical thinking skills is through mobile learning integrated ethnomathematics.
\end{abstract}

KEYWORDS: Ethnomathematics, Learning Media, Logical thinking skill, Mathematical Literacy, Mobile Learning Media

\section{INTRODUCTION}

In the current era of globalization, it takes people who have the skills to find new concepts, open networks, and have the competence to meet high job standards (Hayat \& Yusuf, 2010). The people needed today are not just those who can understand certain sciences, but are deeper than that. Currently, people are required to utilize their knowledge optimally to be more intelligent and critical in receiving and processing information. This is very important to support solving increasingly complex problems. Education has a vital role to face these challenges. Education is a means of preventing risk, as well as a tool that can help improve the quality of human life in a sustainable manner (Moretti \& Frandell, 2013). For this reason, current education is expected to be able to develop students to think creatively, be flexible, solve problems, collaborate, and be innovative skills needed for success in work and life. Education is expected to be able to equip students with the ability to apply their knowledge in everyday life.

These abilities are expected to be developed in education through the subjects taught in schools. Mathematics as one of the compulsory subjects is expected to not only equip students with the ability to use calculations or formulas in doing test questions but also to be able to involve their reasoning and analytical abilities in solving everyday problems. This is in line with the view of NCTM (2000) which makes problem-solving, reasoning and proof, communication, and representation as standard processes in mathematics learning. The demand for students' ability in mathematics is not only to have the ability to count but the ability to reason logically and critically in problem-solving. Solving this problem is not merely a problem in the form of routine questions but rather the problems faced daily. Such mathematical ability is known as mathematical literacy ability.

The ability of elementary school students to understand mathematical literacy has difficulty because mathematics is abstract so it is difficult to understand for elementary school students who are in the concrete operational stage. Therefore, learning media has an important role in building students' mathematical literacy because they can change abstract concepts into concrete ones. The existence of the media is able to provide the same stimulus, equate experiences, and cause the same perception in students. Learning media that are often used in elementary schools are print and graphic media (Mujiani, 2016). This media belongs to the category of non-projected visual media, which functions to channel messages from teachers to students. Examples are pictures/photos, diagrams, charts, posters, graphs, books, modules, and independent teaching materials. The use of print media can provide a pleasant learning experience for students. In addition to being relatively cheap and practical, it is also in accordance with the learning objectives to be achieved. However, the use of media models is much more enjoyable. The model includes threedimensional media. This medium is used when the original object is too large and complex. By using the right and varied media, it can lead to the excitement of learning and overcome the passive attitude of students. 


\section{Evaluating Learning Media on Mathematical Literacy Through Student's Logical Thinking Skill: Mobile Learning Integrated Ethnomathematics as Strategy to Improve Student's Logical Thinking Skill}

Students' mathematical literacy ability can be assessed through students' logical thinking skills which play a role in understanding abstract mathematical problems. The ability to think logically is the ability to think students draw valid conclusions according to the rules of logic and can prove that the conclusions are valid by previous knowledge that is already known (Syaiful, 2011). Sumarto (2006) states that logical thinking is a thinking process that uses reasoning consistently to produce conclusions. Problems or situations that involve logical thinking require structure, relationships between facts, arguments, and a series of understandable lines of reasoning. Based on some of the opinions above, it can be concluded that logical thinking is a thinking process that uses reason consistently following applicable rules to conclude. Logical thinking refers more to understanding, application ability, analytical ability, synthesis ability, and even evaluation ability to form process skills. Based on the description of the problem, researchers are interested in researching to evaluate learning media on mathematical literacy towards the achievement of logical thinking skills and determine strategies to build students' logical thinking skills.

\section{METHODS}

The study was conducted by 79 students from primary schools in Surakarta and Boyolali who have used learning media. The instrument of this research is a test of logical thinking using mathematical literacy. This questionnaire aims to measure the character of students. The data analysis technique in this research is quantitative and qualitative descriptive analysis. The qualitative descriptive analysis is used to process the data obtained from scientific journals to determine the strategy to build students' logical thinking skills. The quantitative descriptive analysis is used to process the data obtained from the test in the form of a descriptive percentage of logical thinking skills. The assessment rubric of logical thinking skill using the level of conceptual understanding with the scale used is score 1 in level no response that is cannot answer or explain, score 2 in level no understanding that is the answer does not make sense scientifically, score 3 in level partial understanding that is the only partial answer is valid and scientific and some misconception, score 4 in a level sound understanding that in answering all aspects with a valid and scientific answer. Students' logical thinking skill aspect was measured as understanding, planning, determining, solving, and conclusion. Indicators on each aspect of students' logical thinking skills using Wulandari dan Fatmahanik (2020) can be seen in table 1.

Table 1. Indicators on each aspect of students' logical thinking skill

\begin{tabular}{|c|c|c|}
\hline No & The aspect of Logical Thinking Skill & The Indicator of logical thinking skill \\
\hline 1 & $\begin{array}{l}\text { Understanding } \\
\text { Making meaning about answers } \\
\text { reasonable argument. }\end{array}$ & $\begin{array}{l}\text { 1. Students are able to understand the meaning of the questions } \\
\text { given. } \\
\text { 2. Students mention all the information from what is known from the } \\
\text { problem (able to formulate the main points of the problem). }\end{array}$ \\
\hline 2 & $\begin{array}{l}\text { Planning } \\
\text { Make logical connections between } \\
\text { different concepts and facts. }\end{array}$ & $\begin{array}{l}\text { 1. Students can plan the solution to the given problem. } \\
\text { 2. Students can express in general all the steps that will be used in } \\
\text { solving the given problem. }\end{array}$ \\
\hline 3 & $\begin{array}{l}\text { Determining } \\
\text { Guess and test based on reason. }\end{array}$ & $\begin{array}{l}\text { 1. Students can determine the strategies or steps that will be used in } \\
\text { solving the problems given. }\end{array}$ \\
\hline 4 & $\begin{array}{l}\text { Solving } \\
\text { Solving mathematical problems } \\
\text { rationally. }\end{array}$ & $\begin{array}{l}\text { 1. Students can solve the problem correctly at each step used } \\
\text { 2. Students determine the truth of each step used in solving the } \\
\text { problem. }\end{array}$ \\
\hline 5 & $\begin{array}{c}\text { Conclusion } \\
\text { Draw logical conclusions. }\end{array}$ & $\begin{array}{l}\text { 1. Students provide conclusions correctly at each step of completion. } \\
\text { 2. Students can conclude correctly on the final result of the answer. }\end{array}$ \\
\hline
\end{tabular}

\section{DISCUSSION}

The material of learning media was analyzed in this study is geometric material which includes flat shapes and spatial shapes. Mathematical literacy tests are distributed to students who get learning media of geometric. Student answer in a mathematical literacy test was analyzed to describe students' logical thinking skill in solving mathematical literacy. Mathematical literacy questions are integrated with ethnomathematics so that the problems raised are in the form of contextual problems that are around students. Logical thinking skill in solving mathematical literacy is thinking skill to make meanings about the answers to reasonable arguments (understanding), make logical connections between different concepts and facts (planning), predict and test based on reason (determining), solve mathematical problems rationally (solving) and draw logical conclusions (conclusion). Percentage achievement of students' logical thinking skills for each category can be seen in Figure 1. 


\section{Evaluating Learning Media on Mathematical Literacy Through Student's Logical Thinking Skill: Mobile Learning Integrated Ethnomathematics as Strategy to Improve Student's Logical Thinking Skill}

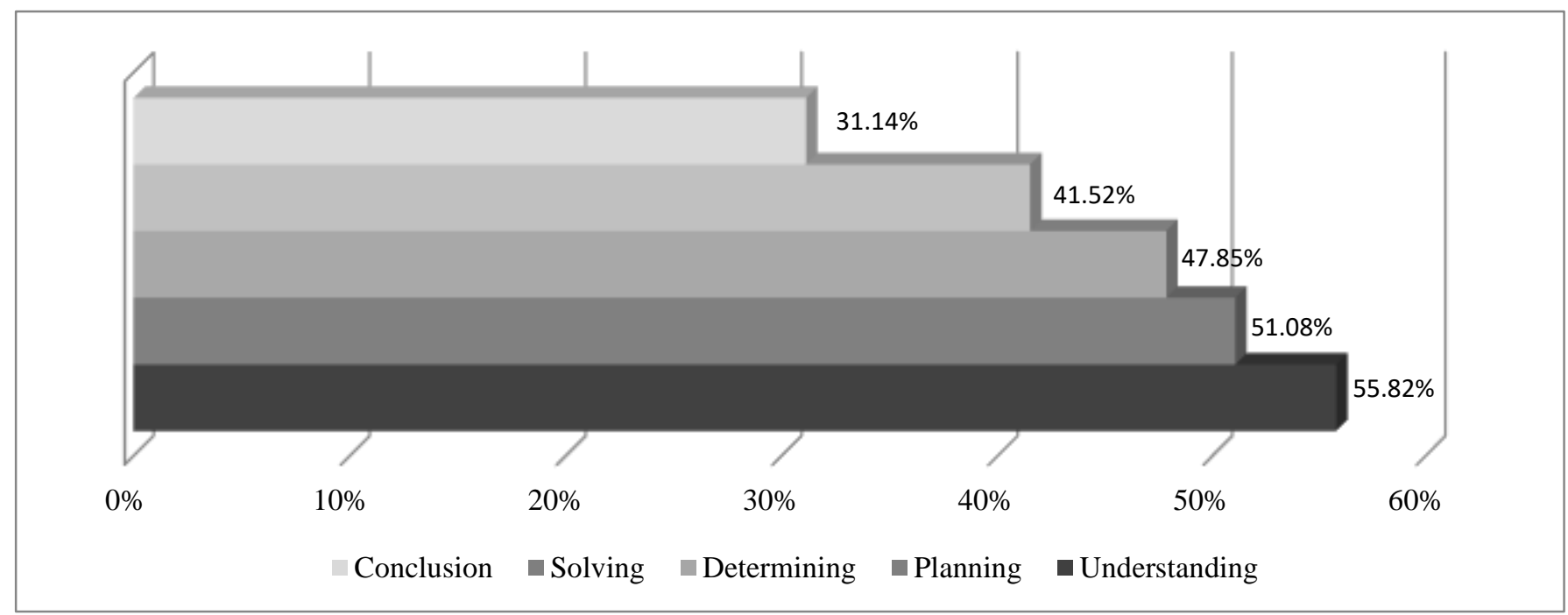

Figure 1: Achievement of students' mathematical logical thinking skills

In Figure 1 it can be seen that the student's achievement of logical-mathematical thinking is still low with the average achievement of mathematical logical thinking skills is $49.07 \%$ with details of understanding (55.82\%), planning (51.08\%), determining (47.85\%), solving (41.52\%) and conclusion (31.14\%). The achievement of the highest mathematical logical thinking skill in the understanding aspect shows that most students can mention all information from what is known from the problem or students can formulate the main points of the problem. The achievement of the lowest mathematical logical thinking skill in the conclusion aspect shows that most students can't provide conclusions correctly at each step of completion. This is because the learning media used is a print learning media that emphasizes more on abstract theories and formulas. This study supports the findings of other studies that learning media is an important tool in developing a conceptual and procedural understanding of mathematical concepts.

One of the learning media that is able to develop conceptual and procedural understanding is learning media that is able to connect mathematics with culture and everyday life, namely ethnomathematics. Ethnomathematics used in the learning process is seen as a bridge for students to develop logical thinking skills because ethnomathematics can be a provider of mathematics learning objects. Materially, mathematical objects are things that represent mathematical concepts in the surrounding environment that grow and develop in the community, but formally mathematical objects are thought objects that are obtained based on concrete objects. Based on this thought, it is understood that ethnomathematics makes a person able to go through a logical thinking process based on patterns and relationships that occur naturally. This is also in line with the logical thinking process, that to be able to think logically one needs to understand the relationship and pattern of a problem faced with one another to then conclude as problem-solving.

The integration of ethnomathematics in learning media will be optimal if the learning media used is interactive learning media that is able to combine audio, visual, and audio-visual such as mobile learning. The use of Mobile Learning as a learning medium is currently very appropriate because IT technology is increasingly experiencing very rapid development, besides the high potential for smartphone use among students. Mobile technology, especially mobile phones, has developed very rapidly. The Radicati Group Inc reported that the world's active mobile phone users reached 5,674 million in 2014 and increased to 5,945 million in 2016. Meanwhile, the total number of cellphones increased from 7,733 million to 9,628 million in 2016 . The ratio of users in 2016 reached 1, 62. It is estimated that in 2018 the ratio of mobile phone users to the world's population 2018 reached 1.95. In Indonesia, the development of mobile phones has the same pattern. The number of mobile phone users in Indonesia increased from $20.6 \%$ in 2005 to $91.7 \%$ in 2010, while the number of computers was only $10.8 \%$ (Pertiwi and Juneman, 2012).

Mobile is a computing device with high mobility. The capabilities of mobile phone hardware continue to increase from time to time. Singh \& Jain (2014) stated that the processor speed and number of smartphone transistors increased 10 times from 2000 to 2010. Therefore, smartphones can replace several computer functions related to learning activities, smartphones can be used as learning support such as doing quizzes, reading ebooks, submitting assignments, sending e-mails, running multimedia content, etc. The rapid development of mobile phones in terms of the number of users and hardware capabilities can be a challenge as well as an opportunity for the world of education (Mahat, et al., 2012; Almaiah, et al., 2016). Some researchers have tried to integrate mobile phones into learning activities so that it is known as mobile learning. As a result, mobile learning has a positive impact on learning activities (Yang, Hwang, Hung, \& Tseng, 2013). Mobile learning gives students the freedom to learn without being limited by time and place. Students and teachers can continue learning, communicating, and interacting outside the formal 


\section{Evaluating Learning Media on Mathematical Literacy Through Student's Logical Thinking Skill: Mobile Learning Integrated Ethnomathematics as Strategy to Improve Student's Logical Thinking Skill}

classroom. Mobile learning makes it easier for teachers to prepare, display, and exchange materials (Almaiah, et al., 2016; Yang \& Lin, 2010; Huang \& Chiu, 2015). Another capability possessed by mobile learning is to increase student involvement in exploration activities and material organization. Teachers are able to monitor progress and record student learning activities to be used as feedback on learning activities (Yang \& Lin, 2010).

Mobile learning media has several advantages including being able to be carried out flexibly anytime and anywhere because smartphones have high characteristics and portability. In addition, learning becomes more effective and efficient because students are more interested in learning mathematics by linking the material to be taught with concrete examples of the mathematical model of the material in everyday life. This is in accordance with the purpose of the study of ethnomathematics, namely so that the relationship between mathematics and culture can be better understood so that students and society's perceptions of mathematics become more precise, and mathematics learning can be more adapted to the cultural context of students and society, and mathematics can be more easily understood. because it is no longer perceived as something 'foreign' by students and society. In addition, the application and benefits of mathematics for the lives of students and the wider community can be optimized, so that students and the community obtain optimal benefits from learning mathematics. Therefore, the role of ethnomathematics is very important as a means of motivation, stimulates students, can overcome boredom, and give new nuances to learning mathematics. Ethnomathematics is already known to students so that in inviting students to identify and relate parts of the culture they already know into a mathematical material with the guidance provided by the teacher it will be easier.

\section{IV.CONCLUSION}

Based on the description of the results and discussion above, it can be concluded that that percentage achievement of students' logical thinking skills in solving mathematical literacy is understanding $(55,82 \%)$, planning $(51,08 \%)$, determining $(47,85 \%)$, solving $(41,52 \%)$, and conclusion $(31,14 \%)$. The data shows that the percentage of students' logical thinking skills is still low. The results of exploration and literature review found that one strategy to build students' logical thinking skills through the use of learning media is by applying mobile learning media integrated ethnomathematics. Mobile learning media integrated ethnomathematic could build logical thinking skill due to learning becomes more effective $\&$ efficient because students are more interested in learning mathematics by linking the material to be taught with concrete examples of the mathematical model material in daily life.

\section{REFERENCES}

1) Almaiah, M. A., Jalil, M. A., \& Man, M. (2016). Extending the TAM to examine the effects of quality features on mobile learning acceptance. Journal of Computers in Education, 3(4), 453-485.

2) Hayat \& Yusuf. (2010). Mutu Pendidikan. Jakarta: Bumi Aksara

3) Huang, Y. M., \& Chiu, P. S. (2015). The effectiveness of a meaningful learning-based evaluation model for context-aware mobile learning. British Journal of Educational Technology, 46(2), 437-447.

4) Mahat, J., Ayub, A. F. M., \& Luan, S. (2012). An assessment of students' mobile self-efficacy, readiness, and personal innovativeness towards mobile learning in higher education in Malaysia. Procedia-Social and Behavioral Sciences, 64 , 284-290.

5) Moretti, G. A. S. \& Frandell, T. (2013). Literacy from a Right to Education Perspective. Report of the Director-General of UNESCO to the United Nations General Assembly 68th Session.

6) Mujiani, D. (2016). Pengaruh media pembelajaran dan kecerdasan logis matematis terhadap hasil belajar matematika siswa. Jurnal Pendidikan Dasar UNJ, 7(2), 199-209.

7) NCTM. (2000). Principles and Standards for School Mathematics, Reston: NCTM.

8) Pertiwi, M., \& Juneman, J. (2012). Peran Pola Asuh Orangtua Dalam Mengembangkan Remaja Menjadi Pelaku Dan/Atau Korban Pembulian Di Sekolah. Sosio Konsepsia: Jurnal Penelitian dan Pengembangan Kesejahteraan Sosial, 17(2), 173-191.

9) Singh, N., Jain, S., \& Sharma, P. (2014). Determinants of proactive environmental management practices in Indian firms: an empirical study. Journal of cleaner production, 66, 469-478.

10) Sumarto. (2006). Konsep Dasar Berpikir; Pengantar ke Arah Berpikir Ilmiah. Makalah Seminar Akademik HUT Ke-40 FE Universitas Nasional "Veteran" Jawa Timur

11) Syaiful. (2011). Peningkatan Kemampuan Berpikir Logis, Kemampuan Pemecahan Masalah Matematis, dan Sikap Siswa Terhadap Matematika Melalui Pendidikan Matematika Realistik. Disertasi SPs: UPI Bandung

12) Wulandari, L., \& Fatmahanik, U. (2020). Kemampuan berpikir logis matematis materi pecahan pada siswa berkemampuan awal tinggi. Laplace: Jurnal Pendidikan Matematika, 3(1), 43-57. 
Evaluating Learning Media on Mathematical Literacy Through Student's Logical Thinking Skill: Mobile Learning Integrated Ethnomathematics as Strategy to Improve Student's Logical Thinking Skill

13) Yang, C. C., Hwang, G. J., Hung, C. M., \& Tseng, S. S. (2013). An evaluation of the learning effectiveness of concept map-based science book reading via mobile devices. Journal of Educational Technology \& Society, 16(3), 167-178.

14) Yang, J. C., \& Lin, Y. L. (2010). Development and evaluation of an interactive mobile learning environment with shared display groupware. Journal of Educational Technology \& Society, 13(1), 195-207. 